\title{
TINJUAN HUKUM MENGENAI VILLA TANPA IJIN AKOMODASI WISATA YANG BEROPERASI DI KOTA DENPASAR
}

\author{
Oleh: \\ A.A Anggun Cintia Dewi*1* \\ I Nengah Suharta***
}

Bagian Hukum Bisnis, Fakultas Hukum, Universitas Udayana

\begin{abstract}
ABSTRAK
Berdasarkan Peraturan Daerah Kota Denpasar Nomor 9 Tahun 2002 Tentang Usaha Pondok Wisata, setiap pelaku usaha pariwisata wajib memiliki ijin kegiatan usaha, termasuk didalamnya pendirian dan pengoperasionalan suatu villa. Tanpa adanya Ijin usaha, kegiatan usaha dalam bentuk apapun di bidang pariwisata dianggap sebagai bentuk kegiatan usaha yang ilegal.

Penerbitan Ijin atau perpanjangan Ijin usaha hotel di daerah Denpasar merupakan bagian dari keputusan atau beschikking yang bersifat hukum publik dalam hukum administrasi yang dilakukan oleh Badan atau Pejabat Tata Usaha Negara dalam hal ini adalah Kepala Dinas PerIjinan Kota Denpasar sesuai dengan Pasal 3 Peraturan Daerah Kota Denpasar Nomor 9 Tahun 2002.

Tujuan dari penelitian ini adalah Untuk mengetahui asalan mengapa pendirian dan operasional suatu villa harus dilengkapi dengan ijin dan untuk mengetahui dan memahami tentang penerapan hukum yang berlaku kepada pelaku usaha penyedia jasa akomodasi Villa di daerah Kota Denpasar yang tidak memiliki Ijin pondok wisata pada usahanya. Metode analisa penelitian ini adalah yuridis empiris.

Hasil penelitian ini adalah dalam melakukan penertiban Villa yang beroperasi tanpa izin menggunakan asas musyawarah. Hal tersebut berarti setiap tindakan yang dilakukan oleh Dinas Pariwisata Kota Denpasar berdasarkan hasil diskusi dengan pihak pemilik maupun pengelola Villa tanpa izin akomodasi wisata tersebut. Prosedur dimulai dari pengecekan izin villa yang dianggap beroperasi tanpa izin akomodasi wisata, pengecekan pembangunan villa tersebut berdasarkan Rencana Tata Ruang Wilayah Propinsi (RTRWP) Peraturan Daerah Kota Denpasar, pengecekan izin mendirikan bangunan (IMB), surat panggilan
\end{abstract}

*) TINJAUAN HUKUM MENGENAI VILLA TANPA IJIN AKOMODASI WISATA YANG BEROPERASI DI KOTA DENPASAR

**)A. A. Anggun Cintia Dewi

***) I Nengah Suharta 
kepada pemilik villa hingga pemberhentian paksa operasional villa bekerja sama dengan kepolisian setempat.

Kata Kunci : villa, ijin akomodasi wisata, Pemerintah Kota

\begin{abstract}
Based on the Regional Regulation of Denpasar City Number 9 of 2002 concerning Pondok Wisata Business, every tourism business actor must have a permit for business activities, including the establishment and operation of a villa. Without a business permit, business activities in any form in the field of tourism are considered as a form of illegal business activity.

Issuance of Permits or extensions of hotel business licenses in the Denpasar area is part of the decision or beschikking that is of public law in administrative law carried out by the Agency or State Administration Officer in this case is the Head of the City of Denpasar Licensing Services in accordance with Article 39 of 2002.

The purpose of this study is to find out the origin of why the establishment and operation of a villa must be equipped with permission and to know and understand the application of applicable laws to Villa accommodation service providers in the area of Denpasar City who do not have a tourism lodge permit on their business. The method of analyzing this research is empirical juridical.

The results of this study are in controlling villas operating without permission using the principle of deliberation. This means that every action taken by the Denpasar City Tourism Office is based on the results of discussions with the owner and manager of the Villa without the tourist accommodation permit. The procedure starts from checking villa permits that are considered operating without a tourist accommodation permit, checking the construction of the villa based on the Provincial Spatial Planning (RTRWP) of Denpasar City Regulations, checking building permits (IMB), summons to villa owners until forced villa dismissal working with the local police.
\end{abstract}

Keywords: villa, tourist accommodation permit, City Government 


\section{PENDAHULUAN}

\subsection{LATAR BELAKANG}

Bali merupakan salah satu daerah tujuan pariwisata tertinggi di Indonesia. Hal tersebut disebabkan karena Bali yang sudah terkenal di dunia berkat keindahan panorama dan budayanya. Semakin meningkatnya penyelenggaraan pariwisata yang mempunyai arti strategis dalam pengembangan ekonomi, sosial dan budaya, yang dapat mendorong peningkatan lapangan kerja. Untuk menata kepariwisataan, pemerintah menerbitkan berbagai peraturan, untuk tingkat nasional pemerintah telah menerbitkan, diantaranyaUndang-Undang No. 10 Tahun 2009 tentang Pariwisata (Lembaran Negara Nomor 11 tahun 2009; Tambahan Lembaran Negara Nomor 4966 ), sedangkan pada tataran daerah, pemerintah daerah menerbitkan dalam bentuk Peraturan Daerah, Peraturan Kepala Daerah dan Keputusan Kepala Daerah.

Berkaitan dengan pengaturan kawasan strategis pariwisata, di kota Denpasar berdasarkan Peraturan Daerah Kota Denpasar Nomor 9 Tahun 2002 Tentang Usaha Pondok Wisata menentukan beberapa kawasan strategis pariwisata di kota Denpasar, diantaranya Pantai Sanur, Taman Budaya Art Centre dan lainnya.Untuk menunjang kegiatan pariwisata di Kota Denpasar, para pelaku usaha menyediakan jasa akomodasi wisata yang beragam di Kota Denpasar, mulai dari guest house, hotel melati, hotel berbintang hingga villa pribadi.

Dewasa ini dirasakan bahwa pembangunan villa di Kota Denpasar semakin marak saja, hal ini dapat dilihat dari banyaknya villa-villa bermunculan baik di area Sanur, area Renon hingga area Teuku Umar. Usaha ini selain memberikan 
keuntungan bagi pelaku usaha juga dapat meningkatkan pendapatan pemerintah daerah Kota Denpasar.

Untuk mendukung operasional sebuah villa, baik peruntukannya maupun pelayananya, termasuk juga fasilitas serta untuk mencapaistandar pendirian usaha akomodasi, maka di perlukan adanya suatu ijin usaha. Seperti dapat dilihat pada data dari Dinas Pariwisata Kota Denpasar, dimana data yang dapat dihimpun mengenai jumlah villa yang terletak di Kota Denpasar seperti berikut:

Tabel 1.1

Jumlah Villa Pada Daerah di Kota Denpasar 2012 - 2018

\begin{tabular}{|l|l|l|}
\hline No & \multicolumn{1}{|c|}{ Tahun } & \multicolumn{1}{|c|}{$\begin{array}{c}\text { Jumlah Villa } \\
\text { Beroperasi }\end{array}$} \\
\hline 1 & 2012 & 15 unit \\
\hline 2 & 2013 & 17 unit \\
\hline 3 & 2014 & 20 unit \\
\hline 4 & 2015 & 22 unit \\
\hline 5 & 2016 & 24 unit \\
\hline 6 & 2017 & 28 unit \\
\hline 7 & 2018 & 30 unit \\
\hline
\end{tabular}

Sumber : Dinas Pariwisata Kota Denpasar

Berdasarkan tabel 1.1 diatas, dapat dilihat pada tahun 2012 terdapat total 15 unit villa yang beroperasi di area Denpasar. Jumlah itu terus meningkat menjadi 17 unit pada tahun 2013, hingga pada tahun 2018 sejumlah 30 unit total unit villa yang beroperasi di Kota Denpasar.

Sebelum pelaku usaha baik perorangan maupun badan hukum yang mengadakan kegiatan usaha villa di daerah Kota Denpasar, langkah awal yang harus dilakukan adalah mengajukan permohonan ijin usaha kepada Pemerintah atau Kepala Instansi 
atau Dinas Pariwisata dan Dinas Perljinan Kota Denpasar disertai identitas pemohon serta persyaratan-persyaratan yang harus di penuhi sesuai dengan ketentuan Peraturan.

Berdasarkan Peraturan Daerah Kota Denpasar Nomor 9 Tahun 2002 Tentang Usaha Pondok Wisata, setiap pelaku usaha pariwisata wajib memiliki ijin kegiatan usaha, termasuk didalamnya pendirian dan pengoperasionalan suatu villa. Tanpa adanya Ijin usaha, kegiatan usaha dalam bentuk apapun di bidang pariwisata dianggap sebagai bentuk kegiatan usaha yang ilegal.

Penerbitan Ijin atau perpanjangan Ijin usaha hotel di daerah Denpasar merupakan bagian dari keputusan atau beschikking yang bersifat hukum publik dalam hukum administrasi yang dilakukan oleh Badan atau Pejabat Tata Usaha Negara dalam hal ini adalah Kepala Dinas PerIjinan Kota Denpasar sesuai dengan Pasal 3 Peraturan Daerah Kota Denpasar Nomor 9 Tahun 2002. Berdasarkan atas latar belakang masalah diatas kajian ini mangangkat sebuah penelitan yang berjudul : "Penertiban Villa

\section{Yang Beroperasi Tanpa Ijin Akomodasi Wisata Di Kota Denpasar"}

\subsection{RUMUSAN MASALAH}

Adapun permasalahan yang dapat peneliti rumuskan adalah

1. Mengapa pendirian dan operasional suatu villa harus dilengkapi dengan ijin?

2. Bagaimanakah prosedur penertiban pelaku usaha akomodasi Villa yang tidak memiliki Ijin pondok wisata untuk Villa di Kota Denpasar? 


\subsection{TUJUAN PENELITIAN}

Tujuan dari penelitian penelitian ini adalah untuk mengetahui asalan mengapa pendirian dan operasional suatu villa harus dilengkapi dengan ijin dan untuk mengetahui dan memahami tentang penerapan hukum yang berlaku kepada pelaku usaha penyedia jasa akomodasi Villa di daerah Kota Denpasar yang tidak memiliki Ijin pondok wisata pada usahanya.

\section{ISI MAKALAH}

\subsection{METODE PENELITIAN}

Pembahasan permasalahan yang ada dalam skripsi ini penulis menggunakan metode penelitian yuridis empiris. Penelitian ini menggunakan penelitian hukum empiris yaitu suatu penelitian yang melakukan dengan observasi atau penelitian dengan secara langsung terjun kelapangan guna untuk mendapatkan kebenaran yang akurat dalam penulisan skripsi. ${ }^{2}$

\subsection{HASIL DAN PEMBAHASAN}

\subsubsection{Peraturan Yang Berlaku Mengenai Pendirian Dan Operasional Villa Di Kota Denpasar}

Jika usaha akomodasi villa yang berdiri dan beroperasional tanpa izin akomodasi wisata, terdapat beberapa resiko dan sanksi yang akan dibebankan kepada manajemen dan pemilik dari usaha villa tersebut.

1. Pengertian dan Jenis Sanksi

Di Indonesia, secara umum, dikenal sekurangkurangnya tiga jenis sanksi hukum yaitu:

a. Sanksi hukum pidana

${ }^{2}$ Soerjono Soekanto.2015.Penelitian Hukum Normatif Suatu Tinjauan Singkat.Rajawali Pers. Jakarta.h.:52 
Dalam hukum pidana, sanksi hukum disebut hukuman. Hukuman adalah Suatu perasaan tidak enak (sengsara) yang dijatuhkan oleh hakim dengan vonis kepada orang yang telah melanggar undang-undang hukum pidana. Hukuman sendiri diatur dalam pasal 10 Kitab Undang-Undang Hukum Pidana (KUHP), yaitu hukuman pokok, yang terbagi menjadi:

1) hukuman mati

2) hukuman penjara

3) hukuman kurungan

4) hukuman denda

Hukuman-hukuman tambahan, yang terbagi menjadi:

1) pencabutan beberapa hak yang tertentu

2) perampasan barang yang tertentu

3) pengumuman keputusan hakim

b. Sanksi hukum perdata

Dalam hukum perdata, putusan yang dijatuhkan oleh hakim dapat berupa:

1) putusan condemnatoir yakni putusan yang bersifat menghukum pihak yang dikalahkan untuk memenuhi prestasi (kewajibannya). Contoh: salah satu pihak dihukum untuk membayar kerugian, pihak yang kalah dihukum untuk membayar biaya perkara

2) putusan declaratoir yakni putusan yang amarnya menciptakan suatu keadaan yang sah menurut hukum. Putusan ini hanya bersifat menerangkan dan menegaskan suatu keadaan 
hukum semata-mata. Contoh: putusan yang menyatakan bahwa penggugat sebagai pemilik yang sah atas tanah sengketa

3) putusan constitutif yakni putusan yang menghilangkan suatu keadaan hukum dan menciptakan keadaan hukum baru. Contoh: putusan yang memutuskan suatu ikatan perkawinan.

c. Sanksi Administrasi/Administratif

Sedangkan untuk sanksi administrasi/administratif, adalah sanksi yang dikenakan terhadap pelanggaran administrasi atau ketentuan undang-undang yang bersifat administratif. Pada umumnya sanksi administrasi/administratif berupa;

1) denda (misalnya yang diatur dalam PP No. 28 Tahun 2008),

2) pembekuan hingga pencabutan sertifikat dan/atau izin (misalnya yang diatur dalam Permenhub No. KM 26 Tahun 2009),

3) penghentian sementara pelayanan administrasi hingga pengurangan jatah produksi (misalnya yang diatur dalam Permenhut No. P.39/MENHUT-II/2008 Tahun 2008),

4) tindakan administratif (misalnya yang diatur dalam Keputusan KPPU No. 252/KPPU/KEP/VII/2008 Tahun 2008)

Berdasarkan wawancara dengan Ir. Anak Agung Bagus Sudharsana selaku Kepala Dinas Pariwisata Kota Denpasar, sanksi administratif tertuang pada Pasal 25 
Peraturan Menteri Kebudayaan Dan Pariwisata Republik Indonesia Nomor PM86/HK.501/MKP/2010 membahas mengenai sanksi administratif yang dapat diberlakukan kepada pemilik dan pengelola usaha akomodasi wisata dimana dijelaskan sebagai berikut:

1. Setiap pengusaha yang tidak memenuhi ketentuan sebagaimana dimaksud dalam Pasal 9 ayat (4), Pasal 18 ayat (4) dan/atau Pasal 20 ayat (3) dikenai teguran tertulis pertama.

2. Apabila dalam jangka waktu 7 (tujuh) hari kerja setelah diberikan teguran tertulis pertama, pengusaha tidak memenuhi ketentuan sebagaimana dimaksud dalam Pasal 9 ayat (4), Pasal 18 ayat (4) dan/atau Pasal 20 ayat (3), pengusaha dikenai teguran tertulis kedua.

Apabila dalam jangka waktu 3 (tiga) hari kerja setelah diberikan teguran tertulis kedua, pengusaha tidak memenuhi ketentuan sebagaimana dimaksud dalam Pasal 9 ayat (4), Pasal 18 ayat (4) dan/atau Pasal 20 ayat (3), pendaftaran usaha pariwisata dibekukan sementara.

Selain itu sanksi administratif villa berdiri dan beroperasional tanpa izin akomodasi wisata dijelaskan melalui Pasal 26 Peraturan Menteri Kebudayaan Dan Pariwisata Republik Indonesia Nomor PM86/HK.501/MKP/2010 tentang sanksi administratif yaitu :

a. Setiap pengusaha yang tidak memenuhi ketentuan sebagaimana dimaksud dalam Pasal 18 ayat (1) dikenai teguran tertulis pertama. 
b. Apabila dalam jangka waktu 30 (tiga puluh) hari kerja setelah diberikan teguran tertulis pertama, pengusaha tidak memenuhi ketentuan sebagaimana dimaksud dalam Pasal 18 ayat (1), pengusaha dikenai teguran tertulis kedua.

c. Apabila dalam jangka waktu 21 (dua puluh satu) hari kerja setelah diberikan teguran tertulis kedua, pengusaha tidak memenuhi ketentuan sebagaimana dimaksud dalam Pasal 18 ayat (1), pengusaha dikenai teguran tertulis ketiga.

d. Apabila dalam jangka waktu 14 (empat belas) hari kerja setelah diberikan teguran tertulis ketiga, pengusaha tidak memenuhi ketentuan sebagaimana dimaksud dalam Pasal 18 ayat (1), pendaftaran usaha pariwisata dibekukan sementara.

Berdasarkan Peraturan Menteri Kebudayaan Dan Pariwisata Republik Indonesia Nomor PM86/HK.501/MKP/2010 pasal 19 mengenai Pembekuan Sementara Dan Pembatalan, dijelaskan bahwa:

a. Bupati, Walikota, atau Gubernur membekukan sementara Tanda Daftar Usaha Pariwisata jika pengusaha :

1) terkena sanksi pembatasan kegiatan usaha dan/atau pembekuan sementara kegiatan usaha sesuai dengan ketentuan peraturan perundang-undangan; atau

2) tidak menyelenggarakan kegiatan usaha secara terusmenerus untuk jangka waktu 6 (enam) bulan atau lebih. 
b. Tanda Daftar Usaha Pariwisata tidak berlaku untuk sementara apabila pendaftaran usaha pariwisata dibekukan sementara.

c. Pengusaha wajib menyerahkan Tanda Daftar Usaha Pariwisata kepada Bupati, Walikota, atau Gubernur paling lambat 14 (empat belas) hari kerja setelah mengalami hal sebagaimana dimaksud pada ayat (1).

\subsubsection{Prosedur Penertiban Usaha Akomodasi Villa Yang Tidak Memiliki Ijin Pondok Wisata Di Kota Denpasar}

Berdasarkan wawancara dengan Bapak Ir. Anak Agung Bagus Sudharsana selaku Kepala Dinas Pariwisata Kota Denpasar, pihak Dinas Pariwisata Kota Denpasar telah bekerja sama dengan Dinas Perijinan dan Tata Ruang Kota Denpasar mengenai penertiban Villa yang beropearasi tanpa izin akomodasi wisata di Kota Denpasar. Fakta lapangan memang menunjukkan terdapat beberapa bangunan yang dibangun dengan izin mendirikan bangunan (IMB) untuk perumahan pribadi, namun disewakan kepada pihak wisatawan sebagai akomodasi wisata villa dan tanpa memiliki izin beroperasi.

Bapak Ir. Anak Agung Bagus Sudharsana menegaskan bahwa prosedur yang dilakukan oleh Dinas Pariwisata Kota Denpasar dalam melakukan penertiban Villa yang beroperasi tanpa izin menggunakan asas musyawarah. Hal tersebut berarti setiap tindakan yang dilakukan oleh Dinas Pariwisata Kota Denpasar berdasarkan hasil diskusi dengan pihak pemilik maupun pengelola Villa tanpa izin akomodasi wisata tersebut. Berikut merupakan prosedur yang dilakukan oleh Dinas Pariwisata Kota Denpasar untuk upaya penertiban akomodasi villa 
yang beroperasi tanpa izin akomodasi wisata resmi di Kota Denpasar:

1. Pihak Dinas Pariwisata Kota Denpasar akan mengecek data villa tersebut di data internal untuk melakukan pengecekan izin yang telah pengusaha villa tersebut miliki.

2. Setelah pengecekan data internal telah diselesaikan dan hasilnya villa tersebut tidak memiliki izin yang seharusnya, maka pihak Dinas Pariwisata Kota Denpasar akan melakukan pengecekan kepada Dinas Tata Kota dan Bangunan Kota Denpasar, mengenai zonasi dari area dimana villa tersebut didirikan.

3. Bila villa tersebut didirikan pada zona pariwisata, maka pihak Dinas Pariwisata Kota Denpasar akan mendatangi pihak pemilik atau pengelola villa tersebut untuk meminta pemilik villa mengurus izin akomodasi wisata.

4. Namun jika villa tersebut didirikan diluar zona pariwisata atau zona pemukiman, maka pihak Dinas Pariwisata Kota Denpasar akan mendatangi pemilik villa untuk menutup kegiatan penerimaan wisatawan karena tidak sesuai peruntukkan area tersebut untuk didirikan usaha akomodasi wisata.

5. Jika saat pihak Dinas Pariwisata Kota Denpasar berusaha menghubungi pihak pemilik atau pengelola villa, namun pemilik villa tidak mengindahkan, maka pihak Dinas Pariwisata Kota Denpasar akan melakukan inspeksi mendadak (sidak) ke lokasi villa tersebut berdasarkan alamat yang didapatkan pada situs online travel agent. 
6. Proses mediasi akan dilakukan oleh pihak Dinas Pariwisata Kota Denpasar, seperti jika terjadi kendala dari pemilik villa dalam melakukan pengurusan perizinan, maka pihak Dinas Pariwisata Kota Denpasar akan berusaha membantu kelancaran dari proses pengajuan izin akomodasi wisata.

7. Jika dalam proses mediasi tidak ditemukan jalan keluar, maka pihak Dinas Pariwisata Kota Denpasar akan bekerja sama dengan pihak kepolisian dan memberi tenggat waktu kepada pemilik villa untuk melakukan pengurusan izin akomodasi wisata tersebut.

8. Apabila izin akomodasi tidak diproses sesuai tenggat waktu yang diberikan, maka pemilik villa akan mendapatkan surat peringatan pertama dari Dinas Pariwisata Kota Denpasar perihal perizinan villa tersebut.

9. Apabila surat peringatan pertama telah lewat dari tenggat waktunya dan tetap saja pemilik villa tidak melakukan proses pengajuan izin akomodasi wisata, maka Dinas Pariwisata Kota Denpasar akan mengeluarkan surat peringatan kedua.

10. Jika masa waktu surat peringatan kedua telah habis dan tetap saja tidak terdapat proses pengajuan izin akomodasi dilakukan oleh pihak pemilik villa, maka Dinas Pariwisata Kota Denpasar akan melakukan penutupan operasional villa tersebut secara paksa yang bekerja sama dengan kepolisian setempat. 


\section{PENUTUP}

Berdasarkan hasil penelitian sebagaimana diuraikan dalam bab-bab sebelumnya, sehingga dapat disimpulkan seperti dibawah ini :

\subsection{Kesimpulan}

1. Peraturan yang berlaku mengenai pendirian dan operasional villa di Kota Denpasar adalah Peraturan Daerah Kota Denpasar Nomor 9 Tahun 2002 Tentang Usaha Pondok Wisata. Peraturan Menteri Kebudayaan Dan Pariwisata Republik Indonesia Nomor PM86/HK.501/MKP/2010 menjelaskan mengenai pendaftaran usaha wisata, Rencana Tata Ruang Wilayah Propinsi (RTRWP) Peraturan Daerah Kota Denpasar No 27 Tahun 2011 tentang Rencana Tata Ruang Wilayah Kota Denpasar tahun 2011-2031, Peraturan Walikota Denpasar No 25 Tahun 2014 tentang Tata Cara Penerbitan Ijin Mendirikan Bangunan dan Undang-Undang Republik Indoneisa No 10 Tahun 2009 Tentang Kepariwisataan.

2. Prosedur penertiban usaha akomodasi villa yang tidak memiliki ijin pondok wisata di Kota Denpasar oleh Dinas Pariwisata Kota Denpasar berdasarkan hasil diskusi dengan pihak pemilik maupun pengelola Villa tanpa izin akomodasi wisata tersebut. Prosedur dimulai dari pengecekan izin villa yang dianggap beroperasi tanpa izin akomodasi wisata, pengecekan pembangunan villa tersebut berdasarkan Rencana Tata Ruang Wilayah Propinsi (RTRWP) Peraturan Daerah Kota Denpasar, pengecekan izin mendirikan bangunan (IMB), surat panggilan kepada pemilik villa 
hingga pemberhentian paksa operasional villa bekerja sama dengan kepolisian setempat.

\subsection{Saran}

1. Disarankan kepada pejabat pengadaan agar melakukan audit internal yang tepat, terutama mengenai HPS (harga perkiraan sendiri) dimana sering terjadi penyimpangan yang tinggi dan berpotensi menyebabkan celah untuk penyedia Barang dan jasa melakukan tindak penyimpangan. Metode penyeleksian aritmatik dari setiap proposal harus dilakukan dengan seksama.

2. Survey harga pasar serta tinjauan langsung baik dilapangan maupun ketempat penyedia Barang dan jasa harus tetap dilakukan dengan rutin. Hal tersebut untuk mencegah penggelembungan dari penyusunan RAB dan HPS, dimana hal tersebut dapat menyebabkan gagal lelang akibat terjadi beberapa kesalahan perhitungan di awal. 


\section{Daftar Pustaka}

\section{Buku :}

Amirrudin dan Zaenal Asikin, 2006, Pengantar Metode Penelitian Hukum, PT Raja Grafindo Persada, Jakarta.

Bambang Waluyo, 1996, Penelitian Hukum Dalam Praktek, Cet II Sinar Grafika Jakarta.

Kartini Kartono, 1995, Metode Pembuatan kertas Kerja atau Skripsi Ilmu Hukum, Mandar Maju, Bandung.

Mustafa Kamal, 2003, Konsep Negara Hukum, Cappris Pubsliher, Jakarta.

Sihite Amar, 2010, Manajemen Perhotelan, CV. Alfabeta, Bandung. Soerjono Soekamto, 2008, Suatu Tinjauan Sosiologi Hukum Terhadap Masalah-Masalah Sosial, PT. Gramedia, Jakarta.

Sugiyono, 2012, Metode Penelitian, Penerbit Gramedia, Jakarta.

Taliziduhu Ndraha, 2003, Kybernologi : Ilmu Pemerintahan Baru, Penerbit PT Rineka Cipta, Jakarta.

\section{Undang-Undang:}

Undang Undang No. 24 Tahun 1992 Tentang Penataan Ruang

(Lembaran Negara Nomor 24 tahun 1992, Tambahan Lembaran Negara Nomor 3501)

Undang-Undang Republik Indonesia Nomor 10.Tahun 2009 Tentang Kepariwisataan. (Lembaran Negara Nomor 11 tahun 2009, Tambahan Lembaran Negara Nomor 4966)

Peraturan Daerah Kota Denpasar Nomor 9 Tahun 2002 Tentang Usaha Pondok Wisata. (Lembaran Negara Nomor 9 tahun 2002, Tambahan Lembaran Negara Nomor 3465)

Peraturan Menteri Kebudayaan Dan Pariwisata Republik Indonesia Nomor PM86/HK.501/MKP/2010 tentang pendaftaran usaha wisata. (Lembaran Negara Nomor 21 tahun 2010, Tambahan Lembaran Negara Nomor 3981) 
Rencana Tata Ruang Wilayah Propinsi (RTRWP) Peraturan Daerah Kota Denpasar No 27 Tahun 2011 tentang Rencana Tata Ruang Wilayah Kota Denpasar tahun 2011-2031. (Lembaran Negara Nomor 16 tahun 2011, Tambahan Lembaran Negara Nomor 5031)

Peraturan Walikota Denpasar No 25 Tahun 2014 tentang Tata Cara Penerbitan Ijin Mendirikan Bangunan. (Lembaran Negara Nomor 7 tahun 2009, Tambahan Lembaran Negara Nomor 5237)

\section{Jurnal Ilmiah :}

Selly Permata Bunda, Kewenangan Dinas Penanaman Modal dan Pelayanan Terpadu Satu Pintu Dalam Pengeluaran Izin Mendirikan Villa Di Kabupaten Pesisir Barat, jurnal penelitian Universitas Lampung, jurnal.fh.unila.ac.id.

Klemens Mandu, Penegakan Hukum Terhadap Usaha Hotel Yang Melanggar Tanda Daftar Usaha Pariwisata Di Kota Denpasar. Ojs.unud.ac.id 